\title{
Age Of Primiparous Mothers Is An Indication Of Cesarean Section
}

\author{
Lisda Handayani ${ }^{1}$, Ibrahim $^{2}$, Adriana Palimbo ${ }^{3}$ \\ \{lisdahandayani@unism.ac.id ${ }^{1}$ Ibrahim.ipb.ac.id@gmail.com ${ }^{2}$, \\ adrianapalimbo@unism.ac.id $\left.{ }^{3}\right\}$ \\ ${ }^{1}$ Faculty of Health, Sari Mulia University, Banjarmasin, Indonesia \\ *lisdahandayani@unism.ac.id
}

\begin{abstract}
Delivery with cesarean section increases in number and percentage every year. The incidence of cesarean section in Indonesia is $9.8 \%$ which the highest proportion is in Jakarta and the lowest is in Southeast Sulawesi, while South Kalimantan has a proportion below that. This study used a cross-sectional approach, the population was mothers who had a cesarean delivery, using the systematic random sampling technique was 350 samples, by using analysis Chi-square test. The proportion of primiparous cesarean delivery at Ansari Hospital at age 20 years 25\%, 20-35 was $21.9 \%$ and age $>35$ was $87.5 \%$. The results analyze obtained $\rho$-value 0.00 ; OR 14,513; CI $(4,009-52,541)$, have a significant relation between age $>35$ years with primiparous mother cesarean birth at Ansari Saleh General Hospital. Primiparous age $>35$ years is an important indication of the cause of cesarean section.
\end{abstract}

Keyword: age, primiparous, childbirth, cesarean section.

\section{Introduction}

Maternal Mortality Ratio is generally used to assess midwifery care in a country or region. mortality rates are still high in the last half-century in part due to a lack of coping with important complications in pregnancy, childbirth, and childbirth, lack of understanding of reproductive health and good obstetric services for all pregnant women [1]. The problem of maternal mortality and disease in Indonesia is still above the average of the WHO target recommended in the 2015 MDG's of 128 / 100,000 live births. Apart from the immediate causes such as bleeding, preeclampsia, infection, due to other factors is the delay factor that increases MMR and IMR in Indonesia, known as 'third delays models', late decision making, late referral, and delay in arriving at the health of the facility due to entering the emergency state [2]. The state of emergency during labor is artificial birth, one of the actions taken is a cesarean section (later called CS).

In the case of childbirth accompanied by complications, CS is one of the deliveries performed to save the mother and the fetus she is carrying. CS measurements are taken if there are abnormalities in the three determinants of labor, was power, parts, and passengers. Furthermore, the comment study of Robson, 2018, suggests that although pregnant women 
have several classifications of primary indications, age factors, nulliparous, primiparous and multiparous (with or without CS surgical scars) are still indications that are taken into account in CS and directly affect other than the overall incidence of caesarean section but also from some indications and complications, for example, between age, parity with pre-eclampsia, age, parity with uterine rupture, and also derived from ethnicity and other epidemiological variables [3]. In the strength factor complication is an indication whether the CS to push, is weak, or the mother has a history of diseases that affect strength. The age of pregnant women who are older than 35 years can also be a reason to perform CS [4]. Based on studies of Vieira, et al. (2015) in Brazil, stated that risk factors for labor with SC in government hospitals include maternal age $<20$ years ( $\mathrm{p}$-value 0.00 ), primigravida ( $\mathrm{p}$-value 0,04$)$, multigravida ( $\mathrm{p}$ value 0.04), and antenatal care more than 6 times (p-value 0.00) [5].

The childbirth with an increase in CS in the number and percentage each year, where the World Health Organization (WHO) sets the rate of CS delivery between $10 \%-15 \%$ of total shipments (WHO, 2015). Basic Health Research (2014) shows that childbirth with CS is $9.8 \%$ with the highest proportion occurring in DKI Jakarta (19.9\%) and the lowest in Southeast Sulawesi $(3.3 \%)$ and South Kalimantan having a proportion below the incidence of CS in Indonesia [6]. This prevalence is in line with the study of Hehir, et al. (2018), in the USA regarding cesarean delivery using the Robson 10-Group Classification System application over a 10-year period (2005-2014), that primiparous and multiparous women who had pre-natal cesarees accounted for more than a quarter of all 31.6 cesarean births \% [7].

Based on the background description of the problem, the reason the researchers chose RSUD Dr. H. Moch. Ansari Saleh because this hospital is the first referral hospital in obstetric emergency referral cases. The incidence of CS delivery increased in the last 3 years, namely in 2013 as many as $9.84 \%$ from 1570 deliveries, in $20149.88 \%$ from 2,239 and in 2015 (January-October 2015) 2,999 deliveries, where the deliveries with CS reached 14, $8 \%$ of 735 primiparous women. Birth rates increase every year, directly proportional to the increase in the percentage and number of CS delivery. So, the problem about the indication of Cesarean of Sectio delivery to primipara mothers in RSUD dr. H. Moch. Ansari Saleh in 2013-2015 needs to be studied.

\section{Method}

This research uses a quantitative approach using a cross-sectional study design. The study population was all primiparous in RSUD dr. H. Moch Ansari Saleh as many as 2,468 mothers, a sample of 344 mothers using a probability sampling technique is random sampling. The type of data is secondary data and bivariate analysis using chi-square. 


\section{Results}

\section{Analysis of Univariate}

General description of the results of the study in the univariate analysis presented each year during the 2013, 2014 and 2015 periods: the number of samples divided by the proportion of sample calculations is 350. Total samples were 91, respectively for 2013, 128 samples for 2014 and 131 samples for 2015.

\section{Cesarean Sectio}

Table 5.1 Distribution of Data by Type of Childbirth to Primipara

\begin{tabular}{ccccccccc}
\hline $\begin{array}{c}\text { Type of } \\
\text { Childbirth }\end{array}$ & \multicolumn{2}{c}{2013} & \multicolumn{2}{c}{2014} & \multicolumn{2}{c}{2015} & \multicolumn{2}{c}{ amount } \\
\cline { 2 - 8 } & $\mathrm{n}$ & $\%$ & $\mathrm{n}$ & $\%$ & $\mathrm{n}$ & $\%$ & $\mathrm{~N}$ & $\%$ \\
\hline $\begin{array}{c}\text { Sectio } \\
\text { Caesarea }\end{array}$ & 22 & 24.2 & 31 & 24.2 & 36 & 27.5 & 89 & 25.4 \\
$\quad(\mathrm{CS})$ & & & & & & & & \\
Non CS & 69 & 75.8 & 97 & 75.8 & 95 & 72.5 & 261 & 74.6 \\
\hline amount & 91 & 100 & 128 & 100 & 131 & 100 & 350 & 100 \\
\hline
\end{tabular}

The type of childbirth is categorized based on labor in sectio caesarea (CS) or Non SC. Table 5.1 shows that the incidence of sectio caesarea (CS) among primiparous women in the period of 2013 to 2015 was $25.4 \%$, while the other $74.6 \%$ were non-SC with a difference in proportion of $49.2 \%$ where non CS delivery was more many compared to CS delivery. Where the incidence of CS increased every year, of $24.2 \%$ in 2103 to 2014, increasing in 2015 to 27.5 $\%$ in line with the increasing number of deliveries.

Age

Table 5.2 Distribution of Data by Age to Primiparous

\begin{tabular}{ccccccccc}
\hline \multirow{2}{*}{ Age (year) } & \multicolumn{2}{c}{2013} & \multicolumn{2}{c}{2014} & \multicolumn{2}{c}{2015} & \multicolumn{2}{c}{ amount } \\
\cline { 2 - 9 } & $\mathrm{n}$ & $\%$ & $\mathrm{n}$ & $\%$ & $\mathrm{n}$ & $\%$ & $\mathrm{~N}$ & $\%$ \\
\hline$<20$ & 15 & 16.5 & 22 & 17.2 & 23 & 17.6 & 60 & 17.1 \\
$20-35$ & 73 & 80.2 & 98 & 76.6 & 103 & 78.6 & 274 & 78.3 \\
$>35$ & 3 & 3,3 & 8 & 6.2 & 5 & 3.8 & 16 & 4.6 \\
\hline amount & 91 & 100 & 128 & 100 & 131 & 100 & 350 & 100 \\
\hline
\end{tabular}


The age variable is categorized into $<20$ years, 20-35 years and $>35$ years. Where age $<20$ years and $>20$ yeras, 35 years is a risky age while ages 20-35 years is called a no-risk age. Based on table 5.2 it is known that the age of primiparous mothers at Dr. H. Moch Ansari Saleh Banjarmasin Hospital is the most aged between 20-35 years, which is $78.3 \%$ of 350 primiparous mothers with almost the same percentage during 2013, 2014 and 2015. Whereas for women> 35 years, $4.6 \%$, where there was an increase in number in 2014 to $6,2 \%$ compared by 2013 , which was $3.3 \%$ if observed from the age of risk, then obtained $21.7 \%$ of primiparous mothers at risk.

\section{Analysis of Bivariate}

\section{Relation between Age and Childbirth CS}

Table 5.3 Relation between Age and Childbirth CS in Primiparous

\begin{tabular}{|c|c|c|c|c|c|c|c|c|}
\hline \multirow{3}{*}{ Age (year) } & \multicolumn{4}{|c|}{ Type of Childbirth } & \multirow{2}{*}{\multicolumn{2}{|c|}{ amount }} & \multirow{3}{*}{$\begin{array}{c}\mathrm{p} \\
\text { value }\end{array}$} & \multirow{3}{*}{$\begin{array}{c}\text { OR } \\
(95 \% \mathrm{CI})\end{array}$} \\
\hline & \multicolumn{2}{|c|}{$\mathrm{SC}$} & \multicolumn{2}{|c|}{ Non SC } & & & & \\
\hline & $\mathrm{n}$ & $\%$ & $\mathrm{n}$ & $\%$ & $\mathrm{~N}$ & $\%$ & & \\
\hline$<20$ & 13 & 25 & 47 & 75 & 60 & 100 & & $0.926(0.471-$ \\
\hline $20-35$ & 60 & 21.9 & 214 & 78.1 & 274 & 100 & ניני. & $1,820)$ \\
\hline$>35$ & 13 & 87.5 & 3 & 12.5 & 16 & 100 & 0.001 & $\begin{array}{c}14,513(4,009- \\
52,541)\end{array}$ \\
\hline
\end{tabular}

Based on table 5.3, mothers who have a risk of $>35$ years of age giving birth as CS are $87.5 \%$ higher when compared to mothers aged 20-35 years or <20 years. The statistical test results obtained p-value 0.001 at the age of the mother $>35$, meaning that there is a difference in the proportion between the age of mother $>35$ with cesarean delivery from primiparous women. The results of the analysis obtained (OR 14.51); 95\% (CI 4.009-52.541), meaning that primiparous with age at risk $>35$ have the possibility of labor by cesarean section 14.5 higher than primiparous with age $20-35$ years. While at the age of mother $<20$ years with pvalue of 0.959 , which means that it is statistically unrelated.

\section{Discussions}

\section{Cesarean Sectio Labor}

Cesarean Sectio (CS) is surgery to remove a child from the uterine cavity by megiris abdominal wall and uterine wall [8]. CS is used to terminate pregnancy or childbirth if it is not possible to have vaginal delivery. In recent times fetal indications have become the most 
common indication for reasons of fetal heart rate. In some circumstances indications can occur from both mother and fetus so that the relative risks cannot be separated easily [9]. CS is a life-saving intervention for specific complications during pregnancy and childbirth that must be available to all women in need. CS provides an increased risk of maternal death and severe acute morbidity and a higher risk for adverse outcomes in subsequent pregnancies compared to vaginal birth. Some CS is associated with a higher risk of maternal morbidity and mortality [10]. Furthermore, related to the study of Sun et al. (2019) in China, about the effects of age and primiparous on elective CS $45 \%$ and $6.9 \%$ of women suffer from anxiety in the third trimester, conclude that young maternal age and low levels of education have an indirect effect on the choice of elective Caesarean section women who influence pregnancy-specific anxiety [11]. This reinforces the importance of age and primipara as an indication of CS.

The rate of childbirth with CS in primiparous mothers in RSUD dr. H. Moch Ansari Saleh Banjarmasin is quite high from year to year which is $24.2 \%$ in 2013 and 2014 and has increased in 2015 to $25.4 \%$. While the number of delivery with the CS set by WHO that $15 \%$ of all deliveries both in the mother primi, multi or grandemultipara so are the maternal figures in sectio caesarea nationally in the last 5 years was $15.3 \%$ (range: $5.5 \%$ in Sulawesi Tenggara; $27.2 \%$ in DKI Jakarta). The percentage increased compared to the results of the 2007 IDHS, which was only $6.8 \%$ [6]. In USA cesarean births that increased from $27 \%$ of all cesarean sections from 2005 to 2006 to > 34\% in 2013 to 2014 [7], in Denmark, CS increased by $49 \%$ between 1998 and 2015 and contributed 21\% of all births [12]. Furthermore, Global discussion is still being debated about the frequency of CS deliveries. Sandall, et.al. (2018), show that, globally, CS use is high and increasing: in 2015, an estimated 29.7 million $(21.1 \%$ ) births occurred by CS, which was almost double the proportion in 2000 (12.1\%). Then, WHO estimates that more than 6.2 million are not medically indicated. CS is conducted every year, $50 \%$ of which are in Brazil and China [10]. And, still related to studies in Brazil, Velhoe et al. (2019), also suggested that cesarean section was significantly associated with age $\geq 35$ years (ORADJ 5,45 95\% CI 3,16-9,39) [13].

The population of CS births in Banjarmasin is quite high when compared to the national rate, which is because this hospital is the first referral center hospital to receive JKN, Jamkesmas, Jamkesprov or general patients, both Bidan Praktik Mandiri (BPM), Poskesdes, Puskesmas or Regional Hospitals, so that the number of childbirth complications is quite high when compared to other hospitals, both government and private hospitals. In addition, another reason is related to the high rate of CS labor in this study because the data taken are only for primiparous mothers, that considered to be more at risk of complications from pregnancy and childbirth.

In general, CS is performed if the mother and fetus have complications during pregnancy and childbirth, are placenta previa, especially placenta previa totalis and subtotalis, and narrow pelvis and other indications such as latitude, tumors that block the birth canal, in pregnancy after vaginal surgery and conditions where attempts to give birth to vaginal children fail. Apart from circumstances that indicate SC events, there are a number of things that might contribute to the high incidence of CS, 'third delays', one of which is a late decision to take action when the mother enters an abnormal condition. This delay still applies to the habits of 
our society, which is influenced by several factors, one of which is decision making. In the social culture of the Banjar community, decisions taken by extended families are husbands, parents, and parents-in-law so decisions are often made late because they wait to discuss first. Several previous studies on CS's decision to prevent maternal death, conducted among others referring from the patient's home to the hospital, barriers arose on the way, access and quality of service, who is helpful at delivery, why are traditional beliefs and habits increasingly being carried out? [14].

Mother's Age

Pregnant women older or younger have a greater risk of complications and at first birth. The importance of age and parity risk factor indications is studied in this CS indication study because it prevents complications from continuing until maternal death. The results of a study in Brazil [5], shows the percentage of CS in primiparous women> 35 years old is higher than those without risk (20-35 years). Age $>35$ years tend to give birth in CS 14.5 times higher than the age of mothers without 95\% risk (CI 4.009-52.541). Age <20 years is known to have no significant correlation with the incidence of CS births in primiparous mothers (p 0.9). Likewise, from the results of multivariate analysis, categorization between maternal age <20 years and $>35$ years at risk and 20-35 years for mothers without risk, indicated that mothers at risk had a 2.355 times greater chance than age without risk 95\% (CI 1,330-4,169). This includes the results that the risk factor for the incidence of labor with SC in government hospitals is $>20$ years of age p 0.003 [5].

The rate of CS delivery in the US according to Cunningham (2006) at an older age occurs in nulliparous groups [15]. Based on research data it is known that mothers with age> 35 years are more at risk of giving birth in SC either with indications of a mother with only a primary or also accompanied by other complications / indications such as KPD, puerperium or pre-delivery. eclampsia. Maternal age has a higher risk of complications in pregnancy and childbirth. The results found complications that occurred in young primiparous mothers who gave birth spontaneously at the Bangil Pasuruan Regional Hospital in 2013 were Early Amniotic Diseases (43.7\%) of 158 respondents. Complications that occurred in elderly primiparous women who gave birth spontaneously at the Bangil Pasuruan Hospital in 2013 were umbilical cord prolapse $(42.8 \%)$ of 7 respondents. In addition, the age of young mothers and primigravida is one of the risk factors in pregnancy and childbirth which is included in the APGO group [16]. As a comparison of aspects of age and parity, the study of Palimbo et al. (2019), in Banjar District, that maternal age has a correlation (OR $=0.27)$; Parity has a correlation value $(\mathrm{OR}=0.26)$. Age and parity of pregnant women are reproductive status in determinants between or as indirect causes of death. In line with the study of [17], in subSaharan Africa, which examined the age of primiparous mothers strongly correlated with spacing of pregnancy, and other studies regarding risk factors as a reference in taking action to deal with the problem of complications [13], [17].

In the concept of nursing and midwifery, there are several experts who put forward concepts and theories related to determinants and risk factors for causes of death. The theory put forward by Varney et al. 2001 [18], that parity is the number of pregnancies that end with the birth of a fetus that is ready to carry on life or at gestational age more than 28 weeks and 
fetal body weight reach more than 1000 grams. The frequency of childbirth experienced by the mother is a condition that can cause the endometrium to become deformed and as a result, complications can occur in pregnancy. According to Cunningham et al. 2006 [14], the mother's safe age during pregnancy and childbirth is 23-35 years. Higher maternal mortality occurs in pregnant and childbirth women under the age of 20 years and after the age of 35 have increased because women who have less than 20 years of age and more than 35 years are considered more vulnerable to the occurrence of preeclampsia. Pregnant women aged $\geq 35$ years experience changes in the uterine tissue and birth canal and decreased the flexibility of the uterine muscle walls so that the risk of preeclampsia/eclampsia. The concept of the review of Bobak et al. 2005 [19], that an estimated $85 \%$ of preeclampsia occurs in the first pregnancy. Parity 2-3 is the safest parity in terms of preeclampsia and the risk increases again in multigravida grande. The etiology of preeclampsia is not known with certainty until now, but several factors that influence the occurrence of preeclampsia, including primigravida / nulliparity, extreme maternal age $(<20$ years and $>35$ years $)$, family history of preeclampsia/eclampsia, kidney disease and existing hypertension before pregnancy, obesity, diabetes mellitus, and trophoblast disease ( $70 \%$ occur in molahidatidosa cases).

\section{Conclusion}

The results of this study support the hypothesis of a very significant correlation between maternal age of primiparous as an indication of CS. This correlation cannot be explained from just one causative factor, but it is important to pay attention to cultural factors of community habits, demographic characteristics, conditions of pregnancy at risk of complications. This also leads the author to discuss decision making and the role of approach and family involvement in understanding 3T, as well as risk factors for maternal pregnancy. In the future also, the authors encourage further research needed the possibility of management of antenatal care at a young age and older age related to the mother's ability to maintain the development of labor.

\section{References}

[1] Prawiroharjo, S: Ilmu Kebidanan. Jakarta: Yayasan Bina Pustaka Sarwono Prawiroharjo. (2010)

[2] Knight, H.E, Self, A, \& Kennedy, S.H, et al,: Why are women dying when they reach hospital on time? A systematic review of the 'Third Delay', Plos One, www.plosone.org., May 2013, V:8 1-5 (2013)

[3] Robson, M.S: Use of indications to identify appropriate caesarean section rates. Lancet Global Health, 6. (8). p e820-e821. (2018)

[4] Pandensolang, R.S: Faktor-faktor yang berhubungan dengan persalinan sectio seasarea pada ibu tanpa riwayat komplikasi dan atau penyulit persalinan di Indonesia (Analisis Data Riskesdas Tahun 2010). Universitas Indonesia (Tesis). (2012) 
[5] Vieira, G.O, Fernandes, L.G, de Oliveira, N.F, Silva, L.R, \& de Oliveira Vieira, T: Factors associated with esarean delivery in public and private hospitals in a city of northeastern Brazil : a cross sectional study. BMC Pregnancy \& Childbirth. 15-132. p 29. (2015)

[6] Kementerian Kesehatan RI: Hasil Riset Kesehatan Dasar 2013. Badan Penelitian dan Pengembangan Kesehatan. Jakarta . (2014)

[7] Hehir, M.P, Ananth, C.V., Siddiq, Z., Flood, K., Friedman, A.M., \& D’Alton, M.E: Cesarean delivery in the United States 2005 through 2014: a population-based analysis using the Robson 10-Group Classification System. AJOG. Elsevier. 219-1.p105.e1105.e11.(2018)

[8] UNPAD. Obstetri Operatif. Bandung: Universitas Padjadjaran. (1987)

[9] Martius, G., Bedah Kebidanan Martius. Bandung: Universitas Padjadjaran.(1987). http://library.poltekkespalembang.ac.id/kepbaturaja/index.php?p=show_detail\&id=712. accessed on November 18, 2019.

[10] Sandall, J., Tribe, R.M., Avery, L., Mola, G., Visser, G.H.A., \& Homer, C.S.E. et al.... : Short-term and long-term effects of caesarean section on the health of women and children. Lancet. 392: 1349-57. (2018)

[11] Sun, Y., Huang, K., Hu, Y.,Yan, S., Xu, Y., Zhu, P., \& Tao, F: Pregnancy-specific anxiety and elective cesarean section in primiparas: A cohort study in China. Plos One. 15(5). p.1-13. (2019)

[12] Velho, M.B., Brüggemann, O.M., McCourt, C., Freitas, P.F., Nogueira da Gama, S.G., Costa, R., \& d'Orsi, R: Prevalence of spontaneous, induced labour or planned caesarean section and factors associated with caesarean section in low-risk women in southern Brazil. Midwifery. Elsevier. 79. 102530. (2019)

[13] Rydahl, E., Declercq, E., Juhl, M., \& Maimburg, R.D: Cesarean section on a rise - Does advanced maternal age explain the increase? A population register-based study. Plos One. 14(1). e0210655. (2019)

[14] Palimbo, A., Salmah, A.U., \& Sari, A: Determinant Factors of Maternal Mortality from 2016 to 2017: A case-control study in Banjar Regency. Indian Journal of Public Health Research \& Development, January 2019, 10 (1). p.385-388. (2019),

[15] Cunningham, F.G: Obstetri Williams. Edisi 1. Jakarta: EGC. (2006)

[16] Istighfarningtyas, M: Komplikasi Persalinan pada ibu primipara muda dan tua di RSUD Bangil Pasuruan Tahun 2013. (Tesis). (2013)

[17] Dunlop, C.L, Benova, L, \& Campbell, O, Effect of maternal age on facilitybaseddelivery: analysis of first-order births in 34 countries of sub-Saharan Africa using demographic and health survey data, BMJ Open. (2018).

[18] Varney, H,. Kriebs, J.M,. \& Gegor, C.L, 2003, Varney's Midwifery, (4th ed.), Sudbury, MA: Jones and Bartlett Publisher, ISBN 0-7637-1856-4, https://books.google.co.id

[19] Bobak, I.L., D., \& Jensen, M: Keperawatan Maternitas. Edisi 4. Alih bahasa: Maria \& Peter. Jakarta: EGC. (2005) 